\title{
Partisipasi Masyarakat Memoderasi Pengaruh PAD, Dana Perimbangan, dan Belanja Modal pada Kinerja Keuangan
}

\author{
Putu Venny Yunita 1 \\ Fakultas Ekonomi dan Bisnis \\ Universitas Udayana, Indonesia \\ Email: venny.ynt@gmail.com
}

\author{
Ni Ketut Rasmini² \\ Fakultas Ekonomi dan Bisnis \\ Universitas Udayana, Indonesia
}

\begin{abstract}
ABSTRAK
Penelitian ini bertujuan untuk menganalisis pengaruh pengaruh pendapatan asli daerah, dana perimbangan, dan belanja modal terhadap kinerja keuangan pemerintah daerah dengan partisipasi masyarakat sebagai variabel pemoderasi. Populasi pada penelitian ini adalah seluruh pemerintah daerah kabupaten dan kota di Provinsi Bali yang terdiri dari 8 kabupaten dan 1 kota dengan periode waktu 5 tahun dari tahun 2014 sampai dengan tahun 2018. Adapun total populasi dalam penelitian ini adalah 45. Teknik sampel yang digunakan adalah sampel jenuh teknik analisis yang digunakan adalah Moderated Regression Analysis (MRA). Hasil penelitian menunjukan bahwa pendapatan asli daerah dan belanja modal berpengaruh positif pada kinerja keuangan pemerintah daerah, sedangkan dana perimbangan tidak berpengaruh pada kinerja keuangan pemerintah daerah. Partisipasi masyarakat memperkuat pengaruh pendapatan asli daerah, dana perimbangan dan belanja modal pada kinerja keuangan pemerintah daerah.
\end{abstract}

Kata Kunci: $\quad$ Pendapatan Asli Daerah; Dana Perimbangan; Belanja Modal; Partisipasi Mayarakat; Kinerja Keuangan.

Community Participation Moderating The Influence of LGR, Fiscal Balance Funds, and Capital Expenditures on The Financial Performance

\begin{abstract}
The research aims to analyze the influence of local government revenue, fiscal balance funds, and capital expenditures on the financial performance of local governments with community participation as a moderating variable. The population in this study were all regency and city governments in Bali Province consisting of 8 regencies and 1 city with a period of 5 years from 2014 to 2018. The total population in this study was 45. The sample technique used was the saturated sample the analysis technique used is Moderated Regression Analysis (MRA). The results of the study showed that the local government revenue and capital expenditure had a positive effect on the financial performance of the regional government, while the fiscal balance fund had no effect on the financial performance of the regional government. Community participation strengthens the influence of local revenue, balance funds and capital expenditure on the financial performance of local governments.
\end{abstract}

Keywords:

Local Government Revenue; Fiscal Balance Fund; Capital Expenditure; Community Participation; Financial Performance.

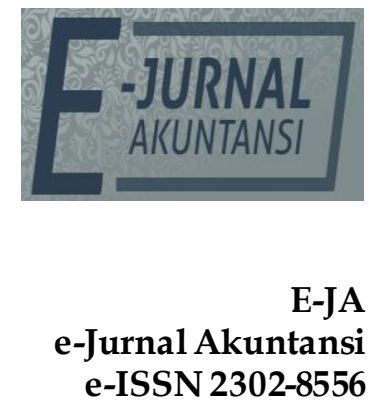

Vol. 30 No. 4

Denpasar, April 2020

Hal.1049-1065

Artikel Masuk:

10 Januari 2020

Tanggal Diterima: 29 Januari 2020 


\section{PENDAHULUAN}

Upaya pemerintah dalam mendorong desentralisasi fiskal belum menunjukan perkembangan yang signifikan. Pasalnya, setiap tahun ketergantungan keuangan daerah pusat masih cukup tinggi. Ketergantungan keuangan daerah menunjukkan bagaimana ketergantungan suatu pemerintah terhadap pendapatan transfer pemerintah pusat dan provinsi (Irwanto et al., 2018). Hal ini pun terjadi pada kabupaten dan kota di Provinsi Bali dimana penerimaan daerah yang berasal dari pendapatan asli daerah, dana perimbangan dan pendapatan lain lain yang sah. Pada dana perimbangan menunjukkan jumlah yang terus meningkat dari tahun ke tahun. Meskipun pendapatan asli daerah meningkat dari tahun ke tahun, tetapi jika dibandingkan dengan dana perimbangan jumlahnya lebih kecil 1,2 persen dari dana perimbangan pada total penerimaan daerah. Berdasarkan data dari Badan Pusat Statistik Provinsi Bali, realisasi penerimaan pendapatan asli daerah dan dana perimbangan daerah Kabupaten/Kota di Provinsi Bali dapat dilihat pada Gambar 1.

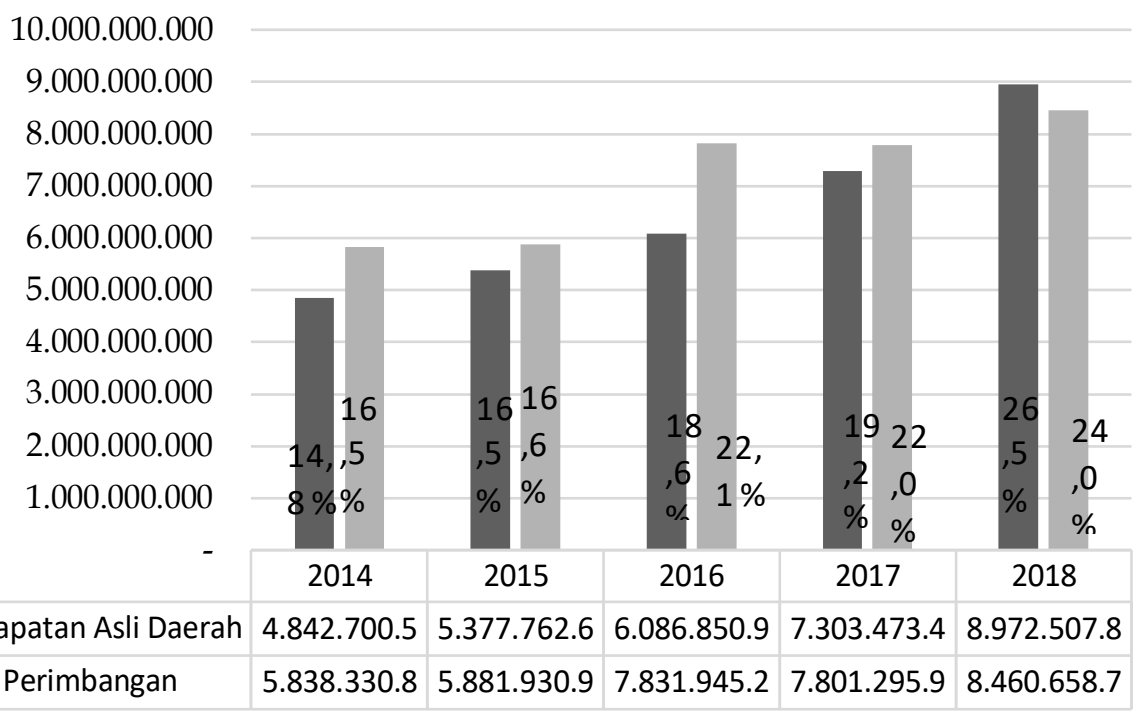

*dalam ribuan rupiah

Gambar 1. Realisasi Penerimaan Pendapatan Asli Daerah dan Dana Perimbangan Daerah Kabupaten/Kota di Provinsi Bali Tahun 2014-2018

Sumber: Badan Pusat Statistik Provinsi Bali, 2019

Rasio dana perimbangan terhadap total pendapatan antar provinsi pada Provinsi Bali berdasarkan data dari Direktorat Jendral Perimbangan Keuangan yaitu sebesar 47,3 persen mengindikasikan bahwa tingkat ketergantungan pemerintah daerah kabupaten dan kota di Provinsi Bali terhadap pemerintah pusat masih tinggi. Dengan meningkatnya penerimaan dana perimbangan yang diterima pemerintah daerah per-tahun seharusnya dimanfaatkan sesuai dengan tujuan utama dari diterimanya dana tersebut, dan juga diimbangi dengan meningkatnya infrastruktur, fasilitas, sarana dan prasarana publik yaitu dengan mengalokasikan penerimaan tersebut untuk meningkatkan kinerja keuangan pemerintah daerah.

Permasalahan lain yang terjadi dalam pengelolaan keuangan daerah adalah persentase dana yang digunakan untuk belanja modal. Rasio belanja modal terhadap total belanja daerah secara nasional tahun 2018 menunjukkan 
penurunan dibanding dengan tahun 2017 sebesar 0,8 persen. Berdasarkan wilayah, pada tahun 2017. Wilayah dengan rasio belanja modal terendah baik pada tahun 2017 ataupun 2018 adalah wilayah Jawa, Sumatera, Kalimantan, Sulawesi, dan Bali dan Nusa Tenggara mengalami penurunan pada rasio belanja modal dari tahun 2017 ke 2018, dengan penurunan terbesar sebesar 1,9 persen. Masih tingginya proporsi anggaran untuk belanja tidak langsung, seperti gaji pegawai, dari pada belanja langsung, baik berupa dana pelayanan publik atau dana investasi yang terkait langsung dengan tujuan organisasi, sehingga mengakibatkan rendahnya nilai kinerja keuangan pemerintah daerah di mata masyarakat, oleh karena itu, tentunya Pemerintah Daerah harus berupaya agar alokasi belanja modal dapat dimanfaatkan dengan lebih baik (Jumiati et al., 2019). Hal ini dibuktikan dengan melihat data pada www.djpk.kemenkeu.go.id rasio belanja modal pada Provinsi Bali hanya 10,2 persen dibandingkan dengan belanja pegawai sebesar 25,9 persen membuktikan bahwa masih rendahnya nilai kinerja keuangan pemerintah daerah di Provinsi Bali.

Pengelolaan keuangan daerah yang baik akan berpengaruh terhadap kemajuan suatu daerah. Pengelolaan keuangan daerah yang dilakukan secara ekonomis, efisien, dan efektif atau memenuhi prinsip value for money serta partisipasi, transparansi, akuntabilitas dan keadilan akan dapat mendorong pertumbuhan ekonomi. Tingkat kemampuan keuangan daerah salah satunya dapat diukur dari besarnya penerimaan daerah khususnya pada pendapatan asli daerah. Pemerintah daerah dalam upayanya menggali kemampuan keuangan daerahnya dapat dilihat melalui kinerja keuangan daerah yang diukur dengan analisi rasio keuangan pemerintah daerah. Pengukuran kinerja keuangan pada pemerintah daerah berfungsi untuk menilai akuntabilitas dan kemampuan keuangan suatu daerah dalam penyelenggaraan otonomi daerah. Maka dari itu suatu daerah yang kinerja keuangannya dinyatakan baik berarti memiliki kemampuan keuangan untuk membiayai pelaksanaan otonomi daerah.

Penilaian kinerja keuangan pemerintah daerah sangat berbeda dengan penilaian kinerja keuangan perusahaan. Selain berbasis anggaran, keuangan pemerintah daerah tidak memiliki tujuan untuk memaksimalkan keuntungan atau laba (profits atau net income), meskipun ada sebutan surplus atau defisit untuk selisih antara pendapatan dan belanja. Surplus/defisit menunjukkan selisih antara pendapatan dan belanja, baik di anggaran pendapatan dan belanja daerah maupun dalam laporan realisasi anggaran. Jika anggaran/realisasi pendapatan lebih besar daripada anggaran/realisasi belanja, maka terjadi surplus, ataupun sebaliknya maka terjadi defisit. Terdapat pemerintah daerah yang mengalami surplus dalam anggaran ataupun realisasi anggarannya, namun lebih banyak pemerintah daerah yang mengalami defisit. Namun, bukan berarti lebih sedikit pemerintah daerah yang kondisi keuangannya baik dibanding yang buruk, karena surplus/defisit bukanlah kunci utama baik buruknya kinerja keuangan pemerintah daerah.

Partisipasi masyarakat merupakan keterlibatan peran sertanya masyarakat dalam kegiatan pemerintahan, sehingga berdampak pada proses evaluasi dan kontrol kinerja pemerintah dan meminimalisir penyalahgunaan wewenang (Yoga \& Rasmini, 2019). Mewujudkan anggaran yang efektif diperlukan partisipasi masyarakat untuk terlibat dalam anggaran pendapatan dan belanja 
daerah dan masyarakat juga ikut mengontrol semua kebijakan pemerintah dilapangan. Dengan partisipasi masyarakat dalam aktif membayar pajak berarti masyarakat ikut membantu pemerintah daerah dalam membiayai pelaksanaan otonomi daerahnya karena masyarakat secara langsung meningkatkan pendapatan asli daerah. Jadi, dengan partisipasi masyarakat ini diharapkan dapat mendorong pemerintah daerah dalam meningkatkan kinerjanya.

Berdasarkan penelitian sebelumnya masih terdapat ketidak konsistenan, hal ini mendorong peneliti untuk meneliti kembali pengaruh belanja modal pada kinerja keuangan pemerintah daerah dan peneliti menambahkan partisipasi masyarakat sebagai variabel pemoderasi. Partisipasi masyarakat dipilih sebagai variabel pemoderasi karena diharapkan dapat mendorong pemerintah daerah dalam meningkatkan kinerjanya. Berdasarkan latar belakang yang telah dijelaskan, maka tujuan penelitian ini adalah untuk menganalisis pengaruh pendapatan asli daerah, dana perimbangan, dan belanja modal pada kinerja keuangan pemerintah daerah dengan partisipasi masyarakat sebagai variabel pemoderasi, sehingga kerangka konseptual penelitian ini dapat dilihat pada Gambar 2.

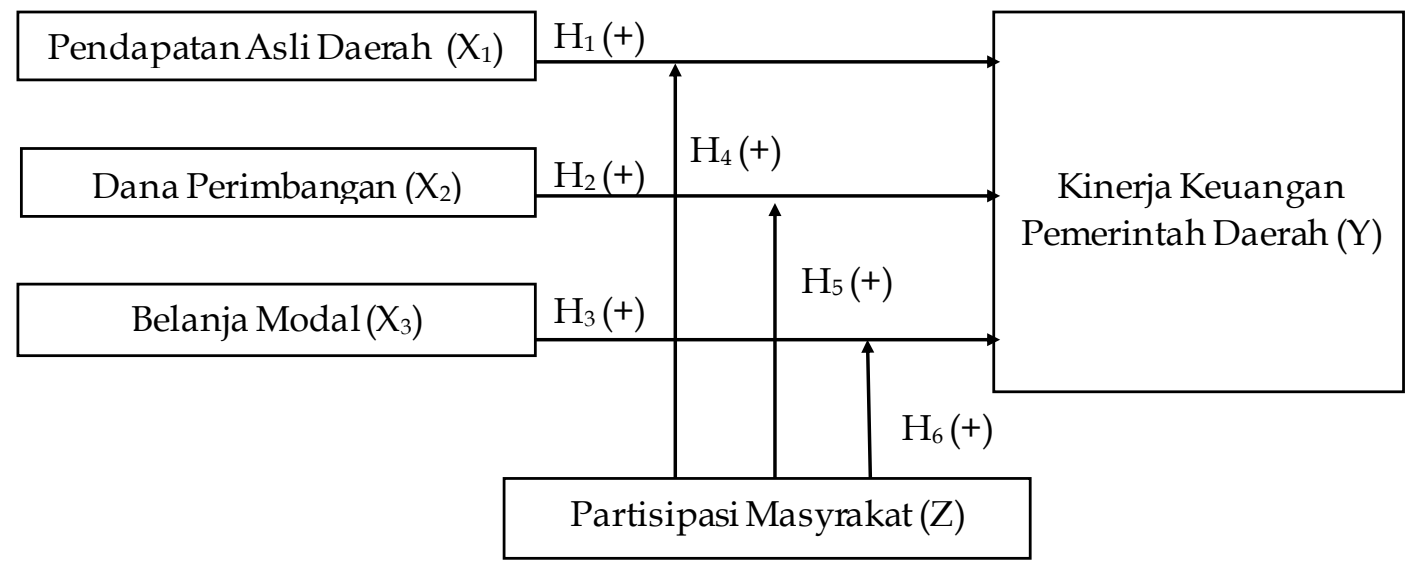

Sumber: Data Penelitian, 2019

Gambar 2. Kerangka Konseptual

Teori agensi berkaitan dengan asimetri informasi dan bentuk pertanggungjawaban pemerintah daerah adalah berupa penyajian laporan keuangan pemerintah daerah yang kemudian laporan ini digunakan oleh masyarakat sebagai dasar untuk penilaian kinerja pemerintah dalam menyelenggarakan fungsi pemerintah termasuk mengelola kuangan daerah. Pemerintah daerah harus selalu meningkatkan kemampuanya untuk menghasilkan keuangan daerah melalui penggalian pendapatan asli daerah atau pendapatan asli daerah harus terus dipacu pertumbuhannya karena kenaikan pendapatan asli daerah ini akan sangat berpengaruh pada kinerja pemerintah daerah Ayu (2018). Semakin tinggi pendapatan asli daerah, semakin tinggi pula kinerja keuangan pemerintah daerah sesuai dengan hasil penelitian Sari (2016), Muhayanah (2016), dan Prasasti (2016) pendapatan asli daerah memiliki pengaruh yang positif dan signifikan terhadap kinerja keuangan pemerintah daerah. Berdasarkan penjelasan tersebut maka dapat dihipotesiskan sebagai berikut: 
$\mathrm{H}_{1}$ : Pendapatan asli daerah berpengaruh positif pada kinerja keuangan pemerintah daerah kabupaten dan kota.

Dana Perimbangan adalah dana yang bersumber dari pendapatan APBN yang dialokasikan kepada daerah untuk mendanai kebutuhan daerah dalam rangka pelaksanaan desentralisasi. Dana perimbangan terdiri dari dana alokasi umum, dana alokasi khusus dan dana bagi hasil ini jelas menunjukkan kinerja fiskal suatu daerah, jika persentase suatu daerah dalam penerimaan dana perimbangan tersebut tinggi, maka dapat disimpulkan bahwa celah fiskal/kapasitas fiskal daerah tersebut rendah, yang juga menunjukkan bagaimana kinerja keuangannya (Alfarisi, 2015). Hal ini berkaitan dengan agensi teori dimana bentuk pertanggungjawaban pemerintah daerah adalah berupa penyajian laporan keuangan pemerintah daerah yang kemudian laporan ini digunakan oleh masyarakat sebagai dasar untuk penilaian kinerja pemerintah dalam menyelenggarakan fungsi pemerintah termasuk mengelola kuangan daerah. Semakin tinggi dana perimbangan, semakin tinggi pula tingkat kinerja keuangan pemerintah daerah sesuai dengan hasil penelitian Sari (2016), Ayu (2018) dan Pratiwi (2018) dana perimbangan berpengaruh positif dan signifikan terhadap kinerja keuangan pemerintah daerah. Berdasarkan penjelasan tersebut maka dapat dihipotesiskan sebagai berikut:

$\mathrm{H}_{2}$ : Dana perimbangan berpengaruh positif pada kinerja keuangan pemerintah daerah kabupaten dan kota.

Belanja modal yang dikeluarkan pemerintah daerah merupakan investasi daerah dalam rangka memberikan pelayanan kepada masyarakat yang manfaatnya baik secara langsung maupun tidak langsung dapat dirasakan oleh masyarakat. Alokasi belanja modal didasarkan pada kebutuhan daerah untuk fasilitas dan infrastruktur baik untuk fasilitas pemerintah maupun publik (Kuntari et al., 2019). Semakin banyak pembangunan yang dilakukan akan meningkatkan kinerja keuangan pemerintah daerah, sesuai dengan logika, semakin banyak sumber yang dihasilkan, maka hasilnya pun akan semakin banyak. Hal ini berkaitan dengan agensi teori dimana penyajian laporan keuangan pemerintah daerah yang kemudian laporan ini digunakan oleh masyarakat sebagai dasar untuk penilaian kinerja pemerintah dalam menyelenggarakan fungsi pemerintah termasuk mengelola kuangan daerah. Semakin tinggi belanja modal, semakin tinggi pula kinerja keuangan pemerintah daerah sesuai dengan hasil penelitian Muhayanah (2016), Ayu (2018), dan Pratiwi (2018) menyatakan belanja modal memiliki pengaruh yang positif dan signifikan terhadap kinerja keuangan pemerintah daerah Berdasarkan penjelasan tersebut maka dapat dihipotesiskan sebagai berikut:

$\mathrm{H}_{3}$ : Belanja modal berpengaruh positif pada kinerja keuangan pemerintah daerah kabupaten dan kota.

Dalam good governance pemerintah tidak menjalankan pemerintahan itu sendiri melainkan ada masyarakat juga yang terlibat sehingga masyarakat dan pemerintah bertanggungjawab serta saling membantu untuk membangun pemerintahan yang baik dan sejahtera. Pemerintah daerah harus selalu meningkatkan kemampuanya untuk menghasilkan keuangan daerah melalui penggalian pendapatan asli daerah harus terus dipacu pertumbuhannya karena kenaikan pendapatan asli daerah ini akan sangat berpengaruh pada kinerja 
pemerintah daerah Ayu (2018). Partisipasi masyrakat dengan turut aktif membayar pajak daerah dapat membantu pemerintah daerah dalam menambah pendapatan daerah, sehingga dengan dengan bertambahnya pendapatan daerah maka akan bertambah pula pendapatan asli daerah yang dihasilkan maka dengan demikian daerah tersebut dikatakan dapat membiayai otonomi daerahnya sendiri. Semakin tinggi pendapatan asli daerah dan semakin tinggi partisipasi masyarakat dalam membayar pajak diharapkan akan semakin mendorong meningkatnya kinerja keuangan pemerintahan daerah. Berdasarkan penjelasan tersebut maka dapat dihipotesiskan sebagai berikut:

$\mathrm{H}_{4}$ : Partisipasi masyarakat memperkuat pengaruh pendapatan asli daerah terhadap kinerja keuangan pemerintah daerah.

Dana perimbangan bertujuan mengurangi kesenjangan fiskal antara pemerintah pusat dan pemerintahan daerah dan antar pemerintah daerah. Dana perimbangan merupakan dana transfer dari pemerintah pusat kepada pemeritah daerah dengan tujuan untuk membiayai kelebihan belanja daerah (Pratiwi, 2018). Partisipasi masyarakat dalam ikut aktif membayar pajak daerah dapat mempengaruhi dana perimbangan yang akan diterima oleh pemerintah daerah kedepannya apakah akan meningkat atau menurun. Sesuai dengan tiga pilar yang saling berkaitan untuk mewujudkan good governance salah satunya adalah partisipasi yang dimana partisipasi yang dimaksudkan adalah partisipasi masyarakat. Semakin tinggi dana perimbangan dan semakin tinggi partisipasi masyarakat dalam membayar pajak diharapkan akan semakin mendorong meningkatnya kinerja pemerintahan. Berdasarkan penjelasan tersebut maka dapat dihipotesiskan sebagai berikut:

$\mathrm{H}_{5}$ : Partisipasi masyarakat memperkuat pengaruh dana perimbangan terhadap kinerja keuangan pemerintah daerah.

Tujuan dilaksanakan good governance pada suatu Negara adalah rakyatnya yang menjadi makmur dan sejahtera. Tercapainya kesejahteraan dan kemakmuran dalam masyarakat salah satunya dengan membutuhkan infrastruktur dan sarana yang dibangun dengan baik dengan belanja modal. Belanja modal yang besar merupakan cerminan banyaknya infratruktur dan sarana yang dibangun. Belanja modal yang efektif dianggap dapat mendorong pertumbuhan ekonomi yang lebih tinggi (Dewi \& Dicriyani, 2018). Semakin banyak pembangunan yang dilakukan akan meningkatkan kinerja keuangan pemerintah daerah, sesuai dengan logika, semakin banyak sumber yang dihasilkan, maka hasilnya pun akan semakin banyak. Dengan tingginya partisipasi masyarakat dalam ikut aktif membayar pajak daerah akan membantu pemerintah dalam membiayai kebutuhan dalam belanja modalnya. Berdasarkan penjelasan tersebut maka dapat dihipotesiskan sebagai berikut:

$\mathrm{H}_{6}$ : Partisipasi masyarakat memperkuat pengaruh dana perimbangan terhadap kinerja keuangan pemerintah daerah.

\section{METODE PENELITIAN}

Penelitian ini merupakan penelitian kuantitatif dengan pendekatan asosiatif, yaitu penelitian yang meneliti mengenai pengaruh pengaruh pendapatan asli daerah, dana perimbangan, dan belanja modal terhadap kinerja keuangan pemerintah daerah dengan partisipasi masyarakat sebagai variabel pemoderasi. 
Penelitian ini dilakukan pada pemerintah daerah kabupaten dan kota di Provinsi Bali yang berjumlah 9 kabupaten/kota terdiri dari 8 kabupaten dan 1 kota. Data penelitian diperoleh dari Badan Pengelola Keuangan dan Aset Daerah (BPKAD) Provinsi Bali yang beralamat di Jl. Teuku Umar No.55, Denpasar, Bali.

Objek penelitian ini adalah data APBD pemerintah daerah kabupaten dan kota di Provinsi Bali yang berjumlah 9 kabupaten dan kota terdiri dari 8 kabupaten dan 1 kota pada periode 2014-2018. Penelitian ini terdiri dari tiga jenis variabel, yaitu variabel dependen, independen dan moderasi. Variabel dependen yang digunakan dalam penelitian ini adalah kinerja keuangan pemerintah daerah $(\mathrm{Y})$.

Kinerja keuangan pemerintah daerah dihitung dengan cara menjumlahkan rasio desentralisasi fiskal, rasio kemandirian keuangan daerah, rasio ketergantungan keuangan daerah. Rumus perhitungan kinerja keuangan pemerintah daerah menurut Mahmudi (2016: 140) adalah sebagai berikut.

$\mathrm{KKPD}=\mathrm{RDF}+\mathrm{RKem}+$ Rket.

Keterangan:

$\mathrm{RDF}=$ Rasio desentralisasi fiskal

RKem $=$ Rasio kemandirian keuangan daerah

RKet $=$ Rasio ketergantungan keuangan daerah

Variabel independen yang digunakan dalam penelitian ini adalah pendapatan asli daerah $\left(X_{1}\right)$, dana perimbangan $\left(X_{2}\right)$, dan belanja modal $\left(X_{3}\right)$. Pendapatan asli daerah merupakan pendapatan daerah yang bersumber dari hasil pajak daerah, hasil retribusi daerah, hasil pengelolaan kekayaan daerah yang dipisahkan, dan lain-lain pendapatan asli daerah yang sah, yang bertujuan untuk memberikan kewenangan kepada pemerintah daerah untuk mendanai pelaksanaan otonomi daerah sesuai dengan potensi daerah sebagai perwujudan desentralisasi Perhitungan rumusnya yaitu:

$P A D=P j D+R D+H P K D+K D D+L L P A D$ yg sah.

Keterangan:

PAD = Pendapatan asli daeah

PjD = Pajak daerah

RD $\quad=$ Retribusi daerah

HPKD = Hasil Pengelolaan Kekayaan Daerah

KDD = Kekayaan daerah yang dipisahkan

LLPAD = Lain-lain pendapatan daerah yang sah

Dana perimbangan adalah dana yang bersumber dari pendapatan APBN yang dialokasikan kepada daerah untuk mendanai kebutuhan daerah dalam rangka pelaksanakan desentralisasi bertujuan untuk menciptakan keseimbangan keuangan antara pemerintah pusat, pemerintah daerah, dan antar pemerintah daerah. Dana perimbangan terdiri dari dana bagi hasil, dana alokasi umum dan dana alokasi khusus. perhitungan rumusnya yaitu:

$D P=D B H+D A U+D A K$.

Keterangan:

$\mathrm{DP} \quad=$ Dana perimbangan

$\mathrm{DBH}=$ Dana bagi hasil

DAU = Dana alokasi umum 
DAK = Dana alokasi khusus

Belanja modal merupakan pengeluaran yang berasal dari suatu anggaran pada pemerintah daerah yang digunakan untuk memperoleh aset tetap atau aset lainnya yang dapat memberi manfaat lebih dari satu periode akuntansi dan digunakan oleh pemerintah daerah dalam menjalankan tugas public service. Perhitungan rumusnya yaitu:

$B M=B T+B P M+B G B+B J I J+B L$

Keterangan:

$\mathrm{BM}=$ Belanja modal

BT = Belanja tanah

$\mathrm{BPM}=$ Belanja peralatan dan mesin

$\mathrm{BGB}=$ Belanja gedung dan bangunan

BJIJ = Belanja jalan, irigasi, dan jaringan

$\mathrm{BL} \quad=$ Belanja lainnya

Variabel moderasi yang digunakan dalam penelitian ini adalah partisipasi masyarakat (Z). Partisipasi masyarakat merupakan peran masyarakat dalam turut serta membiayai penyelenggaran negara yang diwujudkan dengan melakukan pembayaran pajak. Semakin tinggi pendapatan pajak dari masyarakat maka diharapkan semakin tinggi partisipasi masyarakat dalam meningkatkan kinerja pemerintah daerah. Rumus perhitungan partisipasi masyarakat menurut Suprasto (2015:79) adalah sebagai berikut.:

$P M=\frac{P D t_{1}-P D t_{0}}{P D t_{0}}$

Keterangan:

PM = Partisipasi masyrakat

$\mathrm{PD}_{1}=$ Pendapatan daerah tahun saat ini

$\mathrm{PD}_{\mathrm{t}_{0}}=$ Pendapatan daerah tahun sebelumnya

Teknik analisis data yang digunakan dalam penelitian ini terdiri dari uji statistik deskriptif, uji asumsi klasik dan uji Moderated Regression Analysis (MRA). Adapun model rumus yang digunakan mengacu pada (Ghozali, 2016:219).adalah sebagai berikut.

$Y=\alpha_{1}+\beta_{1} X_{1}+\beta_{2} X_{2}+\beta_{3} X_{3}+\beta_{4} Z+\beta_{5} X_{1} Z+\beta_{6} X_{2} Z+\beta_{7} X_{3} Z+\epsilon$

Keterangan:

$\mathrm{Y} \quad=$ Kinerja Keuangan

$\mathrm{X}_{1} \quad=$ Pendapatan Asli Daerah

$\mathrm{X}_{2} \quad=$ Dana Perimbangan

$\mathrm{X}_{3} \quad=$ Belanja Modal

$\mathrm{Z} \quad$ = Partisipasi Masyarakat

a $\quad=$ Konstanta

$\beta_{1}-\beta_{7}=$ Koefisien regresi

e $\quad=$ Tingkat kesalahan (error)

\section{HASIL DAN PEMBAHASAN}

Analisis statistik deskriptif menyampaikan informasi mengenai karakteristik variabel-variabel penelitian yang terdari dari jumlah pengamatan, nilai minimum, nilai maksimum, nilai rata dan standar deviasi. Tabel 1 . memperlihatkan hasil analisis statistik deskriptif. 
Tabel 1. Statistik Deskriptif

\begin{tabular}{lrrrrr}
\hline & $\mathrm{N}$ & \multicolumn{1}{c}{ Minimum } & \multicolumn{1}{c}{ Maximum } & \multicolumn{1}{c}{ Mean } & \multicolumn{1}{c}{$\begin{array}{c}\text { Std. } \\
\text { Deviation }\end{array}$} \\
\hline PAD (dalamjutaan) & 45 & 76.141 & 6.687 .358 & 742.516 & 129.104 \\
$\begin{array}{l}\text { Dana Perimbangan } \\
\text { (dalamjutaan) }\end{array}$ & 45 & 332.251 & 1.313 .915 & 781.850 & 226.876 \\
$\begin{array}{l}\text { Belanja Modal } \\
\text { (dalamjutaan) }\end{array}$ & 45 & 70.217 & 1.649 .106 & 335.740 & 328.677 \\
$\begin{array}{l}\text { Partisipasi Masyarakat } \\
\text { Kinerja Keuangan }\end{array}$ & 45 & $-0,19$ & & & \\
Valid N (listwise) & 45 & 38,16 & 910,48 & 146,58 & 181,34 \\
\hline
\end{tabular}

Sumber: Data Penelitian, 2019

Berdasarkan hasil uji statistik deskriptif pada Tabel 1. menunjukkan jumlah $\mathrm{N}$ sebanyak 45 . Hal ini berarti terdapat 45 data observasi yang diteliti yaitu terdiri dari 9 Kabupaten/Kota selama periode 2014-2018. Pendapatan asli daerah memiliki rata-rata sebesar Rp742.516.946.600,92 dengan nilai standar deviasi Rp129.104.000.000,00 yang jauh lebih rendah dibandingkan nilai ratarata. Nilai minimum dari pendapatan asli daerah sebesar Rp76.141.461.020,04 dimiliki oleh Kabupaten Bangli pada tahun 2014, sedangkan nilai maksimum pendapatan asli daerah sebesar Rp6.687.358.950.260,86 dimiliki oleh Kabupaten Badung pada Tahun 2018.

Dana perimbangan memiliki rata-rata sebesar Rp781.850.904.652,23 dengan nilai standar deviasi Rp226.876.733.246,05 yang jauh lebih rendah dibandingkan nilai rata-rata. Nilai minimum dari dana perimbangan sebesar Rp332.251.562.433 dimiliki oleh Kabupaten Badung pada tahun 2015, sedangkan nilai maksimum dana perimbangan sebesar Rp1.313.915.837.606,00 dimiliki oleh Kabupaten Buleleng pada Tahun 2017.

Belanja modal memiliki rata-rata sebesar Rp335.740.038.048,83 dengan nilai standar deviasi Rp328.677.968.494,35 yang jauh lebih rendah dibandingkan nilai rata-rata. Nilai minimum dari belanja modal sebesar Rp70.217.269.250,00 dimiliki oleh Kabupaten Bangli pada tahun 2014, sedangkan nilai maksimum belanja modal sebesar Rp1.649.106.896.737,98 dimiliki oleh Kabupaten Badung pada Tahun 2018.

Partisipasi masyarakat memiliki rata-rata sebesar 0,2654 dengan nilai standar deviasi 0,36233 yang jauh lebih rendah dibandingkan nilai rata-rata. Nilai minimum dari partisipasi masyarakat sebesar -0,19 dimiliki oleh Kabupaten Tabanan pada tahun 2018, sedangkan nilai maksimum partisipasi masyarakat sebesar 1,80 dimiliki oleh Kabupaten Klungkung pada Tahun 2014.

Kinerja keuangan memiliki rata-rata sebesar 146,58\% dengan nilai standar deviasi $181,34 \%$ yang jauh lebih tinggi dibandingkan nilai rata-rata. Nilai minimum dari kinerja keuangan sebesar 38,16\% dimiliki oleh Kabupaten Karangasem pada tahun 2017, sedangkan nilai maksimum kinerja keuangan sebesar 910,48\% dimiliki oleh Kabupaten Badung pada Tahun 2018

Sebelum melakukan pengujian hipotesis dilakukan uji asumsi klasik terlebih dahulu dengan hasil uji normalitas 0,132 > 0,05; uji autokorelasi 1,937 lebih dari du kurang dari 4-du; uji multikolinieritas setiap variabel lebih besar dari 10\% dan nilai VIF lebih kecil dari 10; uji heteroskedastisitas lebih besar dari 
0,05. Hasil pengujian asumsi klasik dalam penelitian ini sudah memenuhi kriteria pengujian. Pengujian data dalam penelitian ini menggunakan teknik analisis regresi moderasi. Perhitungan koefisien regresi moderasi dilakukan dengan analisis regresi melalui software SPSS, diperoleh hasil yang ditunjukan pada Tabel 2. berikut:

Tabel 2. Hasil Analisis Regresi Moderasi

\begin{tabular}{|c|c|c|c|c|c|c|}
\hline \multirow{2}{*}{\multicolumn{2}{|c|}{ Model }} & \multicolumn{2}{|c|}{$\begin{array}{l}\text { Unstandardized } \\
\text { Coefficients }\end{array}$} & \multirow{2}{*}{$\begin{array}{c}\begin{array}{c}\text { Standardized } \\
\text { Coefficients }\end{array} \\
\text { Beta }\end{array}$} & \multirow[b]{2}{*}{$\mathrm{t}$} & \multirow[b]{2}{*}{ Sig. } \\
\hline & & $\mathrm{B}$ & Std. Error & & & \\
\hline \multirow[t]{12}{*}{1} & (Constant) & $-0,063$ & 0,047 & & $-1,339$ & 0,189 \\
\hline & PAD & 0,339 & 0,057 & 0,316 & 5,902 & 0,000 \\
\hline & Dana Perimbangan & 0,084 & 0,077 & 0,087 & 1,089 & 0,283 \\
\hline & Belanja Modal & 0,362 & 0,052 & 0,370 & 6,904 & 0,000 \\
\hline & Partisipasi Masyarakat & 0,121 & 0,059 & 0,134 & 2,066 & 0,046 \\
\hline & Interaksi X1.Z & 0,395 & 0,080 & 0,362 & 4,961 & 0,000 \\
\hline & Interaksi X2.Z & 0,254 & 0,069 & 0,282 & 3,657 & 0,001 \\
\hline & Interaksi X3.Z & 0,285 & 0,097 & 0,307 & 2,949 & 0,005 \\
\hline & RSquare & 0,949 & & & & \\
\hline & Adjusted R Square & 0,939 & & & & \\
\hline & UjiF & 98,558 & & & & \\
\hline & Signifikansiuji F & 0,000 & & & & \\
\hline
\end{tabular}

Sumber: Data Penelitian, 2019

Nilai adjusted $\mathrm{R}^{2}$ pada Tabel 2 adalah 0,939. Ini berarti variasi kinerja keuangan pemerintah daerah kabupaten dan kota di Provinsi Bali selama periode tahun 2014-2018 dipengaruhi secara signifikan oleh variabel pendapatan asli daerah $\left(X_{1}\right)$, dana perimbangan $\left(X_{2}\right)$, belanja modal $\left(X_{3}\right)$, partisipasi masyarakat $(Z)$, variabel interaksi $X_{1} . Z$, variabel interaksi $X_{2} . Z$ dan variabel interaksi $X_{3} . Z$ sebesar $93,9 \%$ sedangkan sisanya sebesar $6,1 \%$ dijelaskan oleh faktor-faktor lain di luar model.

Nilai $F$ hitung sebesar 98,558 dengan signifikansi $\mathrm{P}$ value 0,000 yang lebih kecil dari $a=0,05$, ini berarti model yang digunakan pada penelitian ini adalah layak. Hasil ini memberikan makna bahwa seluruh variabel independen yaitu pendapatan asli daerah $\left(X_{1}\right)$, dana perimbangan $\left(X_{2}\right)$, belanja modal $\left(X_{3}\right)$, partisipasi masyarakat $(Z)$, variabel interaksi $X_{1} . Z$, variabel interaksi $X_{2} . Z$ dan variabel interaksi $X_{3} . Z$ mampu memprediksi atau menjelaskan fenomena Kinerja Keuangan Pemerintah Daerah Kabupaten dan Kota di Provinsi Bali selama periode tahun 2014-2018. Hal ini berarti model dapat digunakan untuk analisa lebih lanjut atau dengan kata lain model dapat digunakan untuk memproyeksikan karena hasil goodness of fitnya baik dengan nilai signifikansi $\mathrm{P}$ value 0,000 .

Pendapatan asli daerah memiliki nilai signifikansi sebesar 0,000 dengan nilai koefisien regresi sebesar 0,339. Nilai Signifikansi 0,000 $<0,05$ mengindikasikan bahwa $\mathrm{H}_{0}$ ditolak dan $\mathrm{H}_{1}$ diterima. Hal ini menunjukkan bahwa pendapatan asli daerah berpengaruh positif dan signifikan pada kinerja keuangan pemerintah daerah. Hasil ini mendukung penelitian dari Wafa (2018) menyatakan pendapatan asli daerah berpengaruh positif dan signifikan terhadap kinerja keuangan pemerintah daerah kabupaten dan kota. Sejalan dengan hasil penelitian Budianto \& Alexander (2016), Sari (2016), Wijayanto (2017), dan 
Pratiwi (2018) yang membuktikan Pendapatan Asli Daerah memiliki pengaruh yang positif terhadap kinerja keuangan pemerintah daerah, yang mana peningkatan dalam pendapatan asli daerah maka dapat meningkatkan kinerja keuangan daerah. Pendapatan asli daerah yang tinggi merupakan cerminan bahwa pemerintah daerah kabupaten dan kota di provinsi bali sudah mampu untuk membiayai kegiatan otonomi daerahnya sendiri.

Dana perimbangan memiliki nilai signifikansi sebesar 0,283 dengan nilai koefisien regresi positif sebesar 0,084. Nilai Signifikansi 0,283<0,05 mengindikasikan bahwa $\mathrm{H}_{2}$ ditolak. Hasil ini mempunyai arti bahwa dana perimbangan tidak berpengaruh signifikan pada kinerja keuangan pemerintah daerah. Hal ini berkaitan dengan agensi teori dimana bentuk pertanggungjawaban pemerintah daerah adalah berupa penyajian laporan keuangan pemerintah daerah yang kemudian laporan ini digunakan oleh masyarakat sebagai dasar untuk penilaian kinerja pemerintah dalam menyelenggarakan fungsi pemerintah termasuk mengelola kuangan daerah. Hasil penelitian ini sesuai dengan hasil penelitian Wafa (2018) dimana dana perimbangan tidak berpengaruh terhadap kinerja keuangan pemerintah daerah. Serta sejalan dengan penelitian Muhayanah (2016) dan Mardianis (2017) yang menyatakan dana perimbangan tidak berpengaruh terhadap kinerja keuangan pemerintah daerah. Dana perimbangan tidak berpengaruh signifikan pada kinerja keuangan pemerintah daerah mengindikasikan dana perimbangan yang diberikan pemerintah pusat tidak diimbangi dengan tanggung jawab pemerintah daerah dalam mengelola dan memaksimalkan dana transfer pusat untuk kegiatan operasional pemerintahan.

Belanja modal memiliki nilai signifikansi sebesar 0,000 dengan nilai koefisien regresi positif sebesar 0,362. Nilai Signifikansi $0,000<0,05$ mengindikasikan bahwa $\mathrm{H}_{0}$ ditolak dan $\mathrm{H}_{3}$ diterima. Hal ini menunjukkan bahwa belanja modal berpengaruh positif dan signifikan pada kinerja keuangan pemerintah daerah. Semakin banyak pembangunan yang dilakukan akan meningkatkan kinerja keuangan pemerintah daerah, sesuai dengan logika, semakin banyak sumber yang dihasilkan, maka hasilnya pun akan semakin banyak. Hal ini berkaitan dengan agensi teori dimana penyajian laporan keuangan pemerintah daerah yang kemudian laporan ini digunakan oleh masyarakat sebagai dasar untuk penilaian kinerja pemerintah dalam menyelenggarakan fungsi pemerintah termasuk mengelola kuangan daerah. Hasil penelitian ini sesuai dengan penelitian Gina (2018) yang menyatakan Tingginya belanja modal menyebabkan semankin tinggi pula produktivitas perekonomian yang dalam hal ini adalah kinerja keuangan daerah. Penelitian dari Pratiwi (2018), Muhayanah (2016) dan Ayu (2018) juga menyatakan belanja modal memiliki pengaruh yang positif dan signifikan terhadap kinerja keuangan pemerintah daerah. Belanja modal yang tinggi merupakan cerminan dari banyaknya infrastruktur dan sarana yang dibangun. Semakin banyak pembangunan yang dilakukan akan meningkatkan kinerja keuangan pemerintah daerah kabupaten dan kota di provinsi Bali.

Pendapatan asli memiliki nilai signifikansi sebesar 0,000 dengan nilai koefisien regresi positif sebesar 0,339. Nilai signifikansi variabel moderasi partisipasi masyarakat sebesar 0,046 dan nilai signifikan variabel Interaksi antara 
pendapatan asli daerah dan partisipasi masyarakat signifikan sebesar 0,000. Hasil analisis regresi moderasi menunjukkan bahwa nilai koefisien regresi pendapatan asli daerah positif signifikan dan interaksi antara pendapatan asli daerah dan partisipasi masyarakat positif signifikan, maka variabel moderasi partisipasi masyarakat memperkuat pengaruh pendapatan asli daerah pada kinerja keuangan pemerintah daerah. Hasil ini sesuai dengan penelitian Ayu (2018) yang menyatakan bahwa Pemerintah daerah harus selalu meningkatkan kemampuanya untuk menghasilkan keuangan daerah melalui penggalian pendapatan asli daerah yang harus terus dipacu pertumbuhannya karena kenaikan pendapatan asli daerah ini akan sangat berpengaruh pada kinerja pemerintah daerah. Good governance membuktikan bahwa pemerintah tidak menjalankan pemerintahan itu sendiri melainkan ada masyarakat juga yang terlibat sehingga masyarakat dan pemerintah bertanggungjawab serta saling membantu untuk membangun pemerintahan yang baik dan sejahtera. Partisipasi masyrakat dengan turut aktif membayar pajak daerah dapat membantu pemerintah daerah dalam menambah pendapatan daerah, sehingga dengan dengan bertambahnya pendapatan daerah maka akan menambah pendapatan asli daerah yang dihasilkan maka dengan demikian daerah terserbut dikatakan dapat membiayai otonomi daerahnya sendiri

Dana perimbangan memiliki nilai signifikansi sebesar 0,283 dengan nilai koefisien regresi positif sebesar 0,084. Nilai signifikansi variabel moderasi partisipasi masyarakat sebesar 0,046 dan nilai signifikan variabel interaksi antara dana perimbangan dan partisipasi masyarakat signifikan sebesar 0,001. Hasil analisis regresi moderasi menunjukkan bahwa nilai koefisien regresi dana perimbangan positif signifikan dan interaksi antara dana perimbangan dan partisipasi masyarakat positif signifikan, maka variabel moderasi partisipasi masyarakat memperkuat pengaruh dana perimbangan pada kinerja keuangan pemerintah daerah. Hasil ini didukung oleh pernyataan Pratiwi (2018) yang menyatakan bahwa Dana perimbangan bertujuan mengurangi kesenjangan fiskal antara pemerintah pusat dan pemerintahan daerah dan antar pemerintah daerah. Dana Perimbangan merupakan dana transfer dari pemerintah pusat kepada pemeritah daerah dengan tujuan untuk membiayai kelebihan belanja daerah. Dana perimbangan yang meliputi terdiri dari dana alokasi umum, dana alokasi khusus dan dana bagi hasil ini jelas menunjukkan kinerja fiskal suatu daerah. khususnya bagi dana alokasi umum dan dana alokasi khusus, jika persentase suatu daerah dalam penerimaan kedua dana tersebut tinggi, maka dapat disimpulkan bahwa celah fiskal/kapasitas fiskal daerah tersebut rendah, yang juga menunjukkan bagaimana kinerja keuangannya (Alfarisi, 2015). Tiga pilar yang saling berkaitan untuk mewujudkan good governance salah satunya adalah partisipasi yang dimana partisipasi yang dimaksudkan adalah partisipasi masyarakat membuktikan bahwa peran dari partisipasi masyarakat dalam ikut aktif membayar pajak daerah dapat mempengaruhi dana perimbangan yang akan diterima oleh pemerintah daerah kedepannya apakah akan meningkat atau menurun. Semakin tinggi dana perimbangan semakin tinggi partisipasi masyarakat dalam membayar pajak mendorong semakin meningkatnya kinerja pemerintahan 
Belanja modal memiliki nilai signifikansi sebesar 0,000 dengan nilai koefisien regresi positif sebesar 0,362. Nilai Signifikansi variabel moderasi partisipasi masyarakat sebesar 0,046 dan nilai signifikan variabel Interaksi antara belanja modal dan partisipasi masyarakat signifikan sebesar 0,005. Hasil analisis regresi moderasi menunjukkan bahwa nilai koefisien regresi belanja modal positif signifikan dan interaksi antara belanja modal dan partisipasi masyarakat positif signifikan, maka variabel moderasi partisipasi masyarakat memperkuat pengaruh belanja modal pada kinerja keuangan pemerintah daerah.

Tujuan dilaksanakan good governance pada suatu Negara adalah rakyatnya yang menjadi sejahtera dan makmur. Tercapainya kesejahteraan dan kemakmuran dalam masyarakat salah satunya dengan menambah infrastruktur dan sarana yang dibangun dengan baik dengan belanja modal. Hasil ini didukung oleh pernyataan Anggraeni (2016) yang menyatakan bahwa Belanja modal yang besar merupakan cerminan banyaknya infratruktur dan sarana yang dibangun peningkatan pelayanan sektor publik secara berkelanjutan akan meningkatkan sarana dan prasarana publik, investasi pemerintah juga meliputi perbaikan fasilitas pendidikan, kesehatan, dan sarana penunjang lainnya. Semakin banyak pembangunan yang dilakukan akan meningkatkan kinerja keuangan pemerintah daerah. Dengan tingginya partisipasi masyarakat dalam ikut aktif membayar pajak akan membantu pemerintah dalam membiayain kebutuhan dalam belanja modalnya. Maka dari itu semakin tinggi belanja modal semakin tinggi partisipasi masyarakat dalam membayar pajak mendorong semakin meningkatnya kinerja pemerintahan.

Hasil penelitian ini mampu memberikan tambahan informasi empiris tentang pengaruh pendapatan asli daerah, dana perimbangan, dan belanja modal terhadap kinerja keuangan pemerintah daerah dengan partisipasi masyarakat sebagai pemoderasi. Penelitian ini mendukung agency theory yang berhubungan dengan fenomena pendapatan asli daerah, dana perimbangan, belanja modal pada kinerja keuangan pemerintah daerah dengan partisipasi masyarakat sebagai variabel moderasi. Hasil penelitian ini juga mendukung teori good governance dimana pemerintah tidak menjalankan pemerintahan itu sendiri melainkan ada masyarakat juga yang terlibat sehingga masyarakat dan pemerintah bertanggungjawab serta saling membantu untuk membangun pemerintahan yang baik dan sejahtera. Hasil penelitian ini dapat dijadikan refrensi konseptual serta perbandingan, pengembangan, dan penyempurnaan berkaitan dengan variabel terkait.

Hasil penelitian ini mampu memberikan kontribusi bagi pihak-pihak yang berkepentingan khususnya pemerintah daerah kabupaten dan kota pada bagian pendapatan asli daerah, dana perimbangan, belanja modal serta peran dari partisipasi masyarakat. Penelitian ini mengimplikasi bahwa hasil dari pendapatan asli daerah, belanja modal serta partisipasi masyarakat memberi dampak yang cukup tinggi terhadap kinerja keuangan. Pemerintah daerah dapat memperhitungkan kembali dlaam penggunaan dana perimbangan dari pemerintah pusat dengan baik sehinga dapat memberikan kontribusi pada kinerja keuangan. 


\section{SIMPULAN}

Simpulan dalam penelitian ini yaitu pertama, pendapatan asli daerah berpengaruh positif pada kinerja keuangan pemerintah daerah. Hal ini menunjukkan bahwa semakin tinggi pendapatan asli daerah, maka kinerja keuangan pemerintah daerah kabupaten dan kota di Provinsi Bali akan meningkat. Kedua, dana perimbangan tidak berpengaruh pada kinerja keuangan pemerintah daerah. Hal ini menunjukkan bahwa besar atau kecilnya dana perimbangan yang diberikan pemerintah pusat tidak mempengaruhi kinerja keuangan yang dihasilkan oleh pemerintah daerah Provinsi Bali. Ketiga, belanja modal berpengaruh positif pada kinerja keuangan pemerintah daerah. Hal ini menunjukkan bahwa semakin tinggi belanja modal, maka kinerja keuangan pemerintah daerah kabupaten dan kota di Provinsi Bali akan meningkat. Keempat, partisipasi masyarakat memperkuat pengaruh pendapatan asli daerah pada kinerja keuangan pemerintah daerah. Hal ini berarti bahwa adanya partisipasi masyarakat mampu memperkuat hubungan antara pendapatan asli daerah dan kinerja keuangan pemerintah daerah kabupaten dan kota di Provinsi Bali, dimana partisipasi masyarakat mendorong pemerintah daerah dalam menambah pendapatan daerah yang secara langsung meningkatkan pendapatan asli daerah sehingga kinerja keuangan daerah juga akan meningkat. Kelima, partisipasi masyarakat memperkuat pengaruh dana perimbangan pada kinerja keuangan pemerintah daerah. Hal ini berarti bahwa adanya partisipasi masyarakat mampu memperkuat hubungan antara dana perimbangan dan kinerja keuangan pemerintah daerah kabupaten dan kota di Provinsi Bali, dimana partisipasi masyarakat mendorong pemerintah daerah dalam meningkatkan pendapatan daerah, yang dapat digunakan untuk membantu dana perimbangan yang digunakan untuk meningkatkan kinerja keuangan daerah. Keenam, partisipasi masyarakat memperkuat pengaruh belanja modal pada kinerja keuangan pemerintah daerah. Hal ini berarti bahwa adanya partisipasi masyarakat mampu memperkuat hubungan antara belanja modal dan kinerja keuangan pemerintah daerah kabupaten dan kota di Provinsi Bali, dimana partisipasi masyarakat mendorong pemerintah daerah dalam meningkatkan pendapatan daerah, yang dapat digunakan unutuk meningkatkan belanja modal sehingga kinerja keuangan daerah juga akan meningkat.

\section{REFERENSI}

Abdullah \& Dri, A. (2016). Pengaruh Pendapatan Asli Daerah, Dana Alokasi Umum, dan Alokasi Khusus Terhadap Kinerja Keuangan Pemerintah Daerah Kabupaten/Kota Se-Sumatera Bagian Selatan. Jurnal Akuntansi, 3(1), 41-67.

Alfarisi, S. (2015). Pengaruh Pajak Daerah, Retribusi Daerah, Dan Dana Perimbangan Terhadap Kinerja Keuangan Pemerintah Daerah (Studi Empiris pada Kabupaten dan Kota di Provinsi Sumatera Barat). Jurnal Akuntansi Universitas Negeri Padang, 3(1), 1-25. Retrieved from http://ejournal.unp.ac.id/students/index.php/akt/article/download/1651 $/ 1274$

Anggraeni, A., \& Yogyakarta, U. M. (2016). Pengaruh Belanja Modal Terhadap Kinerja Keuangan dengan Pendapatan Asli Daerah Sebagai Variabel 
Intervening. Jurnal Akuntansi Fakultas Ekonomi Dan Bisnis, 1-18. Retrieved from http://repository.umy.ac.id/handle/123456789/8707

Ayu, P. P. (2018). Analisis PAD dan Dana Perimbangan Terhadap Kinerja Keuangan Pemda Se-Jawa Barat. Jurnal Akuntasi \& Ekonomi, 3(1), 80-96.

Badan Pusat Statistik. (2019). Realisasi Penerimaan Pendapatan Asli Daerah dan Dana Perimbangan Daerah Kabupaten dan Kota di Provinsi Bali. Bali.

Bolen, K. K. (2019). The Effect of Financial Performance and Balanced Funds on Capital Expenditure of Local Government in District / City in Indonesia. Journal of Public Administration and Governance, 9(4), 129-147. https://doi.org/10.5296/jpag.v9i4.15583

Budianto, B., \& Alexander, S. (2016). Pengaruh Pad Dan Dana Perimbangan Terhadap Kinerja Keuangan Pemerintah Kabupaten/Kota Di Provinsi Sulawesi Utara. Jurnal Riset Ekonomi, Manajemen, Bisnis Dan Akuntansi, 4(4), 844-851.

Darise. N. (2008). Akuntansi Keuangan Daerah, Akuntansi sektor Publik. Jakarta: Indeks.

Dewi, N. L. P. S., \& Dicriyani, N. L. gede M. (2018). Factors Affecting the Capital Expenditures in Bali Province. JASF Journal of Accounting and Strategic Finance, 1(2), 143-152. https://doi.org/10.33005/jasf.v1i02.30

Direktorat Jendral Perimbangan Keuangan. (2018). Ringkasan APBD 2018. September. DJPK. Indonesia

Djaenuri. Aries. (2012). Hubungan Keuangan Pusat-Daerah. Ghalia Indonesia: Jakarta.

Djuniar, L., \& Zuraida, I. (2018). Pengaruh Pendapatan Asli Daerah (Pad), Belanja Modal Dan Sisa Lebih Pembiayaan Anggaran (Silpa) Terhadap Kinerja Pemerintah Daerah Kabupaten/Kota Provinsi Sumatera Selatan. BALANCE Jurnal Akuntansi Dan Bisnis, 3(2), 445-455. https://doi.org/10.32502/jab.v3i2.1447

Gina Sukma Antari, N. P., \& Panji Sedana, I. B. (2018). Pengaruh Pendapatan Asli Daerah Dan Belanja Modal Terhadap Kinerja Keuangan Pemerintah Daerah. E-Jurnal Manajemen Unud, 7(2), 1080-1110.

Ghozali. (2016). Aplikasi Analisis Multivariete Dengan Program IBM SPSS. Semarang: Badan Penerbit Universitas Diponegoro.

Halim, A., \& Abdullah, S. (2006). Hubungan dan Masalah Keagenan di Pemerintah Daerah: Sebuah Peluang Penelitian Anggaran dan Akuntansi. Jurnal Akuntansi Pemerintahan, 2(1), 53-64.

Halim, Abdul. (2012). Akuntansi Sektor Publik: Akuntansi Keuangan Daerah. Jakarta: Salemba Empat.

Haryanto, J. T. (2017). Mapping the Local Own Resources (PAD) Performance and Regional Dependence in Indonesia 2008-2014: Quadrant Method Approach. Jurnal Bina Praja, 9(1), 41-52. https://doi.org/10.21787/jbp.09.2017.41-52

Irwanto, Titisari, K. H., \& Chomsatu, Y. (2018). Influence of Regional Financial Responsibility, Degree of Fiscal Desentralization and Level Financing Level to Allocation of Capital Government Regency / Central Java City. International Conference on Economics, Business and Economic Education, 2018, 747-759. https://doi.org/10.18502/kss.v3i10.3169 
Jensen, M. C., \& Meckling, W. H. (1976). Theory Of The Firm: Managerial Behavior, Agency Costs And Ownership Structure. Journal of Financial Economics, 3, 305-360.

Jumiati, E., Indriani, M., \& Darwanis. (2019). The Influence of Regional Revenue , Balance Funds, Special Autonomy Funds, and Economic Growth on Capital Expenditure Allocation Economic Growth, Capital Expenditure Allocation. Journal of Accounting Research, Organization and Economics, 2(2), 90-97.

Kuntari, Y., Chariri, A., \& Prabowo, T. J. W. (2019). Capital Expenditure Of Local Governments. Academy of Accounting and Financial Studies Journal, 23(1), 113.

Mardianis, \& Enggar D.P Arum, H. A. (2017). Pengaruh Pendapatan Asli Daerah (Pad), Dana Perimbangan, Belanja Daerah Dan Opini Audit Bpk Terhadap Kinerja Pemerintah Daerah Kabupaten/Kota Di Provinsi Jambi. Jurnal Akuntansi \& Keuangan Magister Ilmu Akuntansi Universitas Negeri Jambi, 2(3), 13-28.

Mahmudi. (2016). Analisis Laporan Keuangan Pemerintah Daerah. Yogyakarta: STIM YKPN.

Mahsun. M. (2013). Pengukuran Kinerja Sektor Publik. Penerbit BPFE: Yogyakarta.

Malau, E. I., Erlina, \& Sirojuzilam. (2019). The Effect Of Local Government Revenue (Lgr), Balance Fund, Capital Expenditure And Fiscal Stress On The Financial Performance Of Regional Government In The District / City Of Sumatera Utara Province Eve. International Journal of Public Budgeting, Accounting, And Finance, 2(2), 1-15.

Mardiasmo. (2018). Akuntansi Sektor Publik. Yogyakarta: ANDI.

Muda, I., \& Ridha, H. (2018). Effect of Revenue and General Allocation Fund of Capital Expenditures in the Economic Growth as Moderator Variable . Case of Indonesia. Academic Journal of Economic Studies Vol. , 4(1), 29-39.

Muhayanah, F. A. (2016). Pengaruh Pendapatan Asli Daerah, Dana Perimbangan Dan Belanja Modal Terhadap Kinerja Keuangan Pemerintah Daerah Kabupaten Dan Kota Di Provinsi Jawa Tengah Tahun 2012-2013. Retrieved from http://eprints.ums.ac.id/id/eprint/43837

Mulyani, H. (2016). The Relationship of Local Own Revenues and General Fund Allocation on Capital Expenditure of Local Government. Advances in Economics, Business and Management Research, 15, 163-166.

Nugraha, Yoga. (2019). Desentralisasi dan Ketergantungan Fiskal Daerah. News Detik.

Peraturan Pemerintah Republik Indonesia Nomor 12 Tahun 2019 tentang Pengelolaan Keuangan Daerah. (2019). Indonesia

Peraturan Menteri Keuangan Nomor : 91 /PMK.06/2007 tentang Bagan Akun Standar. (2007). Indonesia

Prasasti, S., \& Sari, R. (2016). Pengaruh Pendapatan Asli Daerah (Pad) Dan Dana Perimbangan Terhadap Kinerja Keuangan Pemerintah Daerah (Studi Kasus Pemerintah Daerah Kabupaten/Kota Diy Tahun 2007-2013). Akmenika: Jurnal Akuntansi Dan Manajemen, 12(1), 1-13.

Pratiwi, T. Y. (2018). Pengaruh Pendapatan Asli Daerah, Dana Perimbangan, Dan Belanja Modal Terhadap Kinerja Keuangan Pemerintah Daerah Kabupaten Dan 
Kota Di Provinsi Jawa Tengah Tahun Anggaran 2012-2016.

Purba, I. B. A. H., \& Mimba, N. P. S. H. (2019). Analysis on the Regional Financial Performance of Regencies / Cities in Bali Province. Journal Of Humanities And Social Science, 24(1), 20-33. https://doi.org/10.9790/0837-2401092033

Sari, I. P. (2016). Pengaruh Ukuran Pemerintah Daerah, Pad, Leverage, Dana Perimbangan Dan Ukuran Legislatif Terhadap Kinerja Keuangan Pemerintah Daerah (Studi pada Kab/Kota Pulau Sumatra). JOM Fekom, 3(1), 679-692.

Sari, P., Garvera, R. R., \& Sihabudin, A. A. (2018). What is the Contribution of Local Original Revenue to Regional Financial Independent? Journal of Public Administration Studies, 3(1), 33-36.

Sari, P. R., Tjahjono, H., \& Turino. (2018). Analysis Of Financial Performance In Public Sector (A Case Study in Lamongan, East Java-Indonesia). Journal of Accounting and Strategic Finance, 1(1), 82-90. https://doi.org/10.33005/jasf.v1i01.35

Suryatini, N. P. S., Damayanti, N. P. A., \& Candraninggrat, I. R. (2018). The Effect Of Regional Financial Performance On Capital Expenditure And Economic Growth In Each District / Cities In Bali Province. International Journal of Economics, Commerce and Management, VI(11), 673-686.

Suwiknyo, Edi. (2019). Desentralisasi Fiskal Belum Optimal, Ketergantungan Daerah ke Pusat Masih Tinggi. Bisnis.com

Undang-Undang Nomor 33 Tahun 2004 tentang Perimbangan Keuangan Antara Pemerintah Pusat dan Pemerintah Daerah. (2004). Indonesia.

Undang-Undang Nomor 23 Tahun 2014 tentang Pemerintah Daerah. (2014). Indonesia.

Wafa, M. Si. (2018). Pengaruh Pendapatan Asli Daerah, Ukuran Pemerintah Daerah, Leverage, Dana Perimbangan, Dan Belanja Modal Terhadap Kinerja Keuangan Pemerintah Daerah. https://doi.org/10.1017/CBO9781107415324.004

Wahyuningsih, Y. E. (2016). Pengaruh Pendapatan Asli Daerah (Pad) Dan Dana Perimbangan Terhadap Kinerja Keuangan Pemerintah Kabupaten/Kota Di Provinsi Jawa Tengah.

Wijayanto, R. (2017). Fakultas ekonomi dan bisnis universitas muhammadiyah yogyakarta 2017.

Wulandari, E., Wahyudi, M., \& Rani, U. (2018). Effect of Original Local Government Revenues, General Allocation Funds, Special Allocation Funds, Share Funds, Other Legal Revenues, Budget Surplus / Deficit to Human Development Index Through Capital Expenditures : Case Study of Regencies / Municipa. Review of Integrative Business and Economics Research, 7(2), 125-137.

Yoga Darma Putra, I. M., \& Rasmini, N. K. (2019). Pengaruh Akuntabilitas, Transparansi, dan Partisipasi Masyarakat Pada Efektivitas Pengelolaan Dana Desa. E-Jurnal Akuntansi, 28(1), 132-158. 